University of Nebraska - Lincoln

DigitalCommons@University of Nebraska - Lincoln

2004

\title{
Modeling impacts on populations: fathead minnow (Pimephales promelas) exposure to the endocrine disruptor $17 \beta$-trenbolone as a case study
}

\author{
David H. Miller \\ US Environmental Protection Agency \\ Gerald T. Ankley \\ US Environmental Protection Agency
}

Follow this and additional works at: https://digitalcommons.unl.edu/usepapapers

Part of the Civil and Environmental Engineering Commons

Miller, David H. and Ankley, Gerald T., "Modeling impacts on populations: fathead minnow (Pimephales promelas) exposure to the endocrine disruptor $17 \beta$-trenbolone as a case study" (2004). U.S. Environmental Protection Agency Papers. 16.

https://digitalcommons.unl.edu/usepapapers/16

This Article is brought to you for free and open access by the U.S. Environmental Protection Agency at DigitalCommons@University of Nebraska - Lincoln. It has been accepted for inclusion in U.S. Environmental Protection Agency Papers by an authorized administrator of DigitalCommons@University of Nebraska - Lincoln. 


\title{
Modeling impacts on populations: fathead minnow (Pimephales promelas) exposure to the endocrine disruptor $17 \beta$-trenbolone as a case study
}

\author{
David H. Miller ${ }^{\mathrm{a}, *}$ and Gerald T. Ankley ${ }^{\mathrm{b}}$ \\ ${ }^{a}$ Mid-Continent Ecology Division, National Health and Environmental Effects Research Laboratory, US Environmental Protection Agency, \\ 9311 Groh Rd., Grosse Ile, MI 48138, USA \\ ${ }^{\mathrm{b}}$ Mid-Continent Ecology Division, National Health and Environmental Effects Research Laboratory, US Environmental Protection Agency, \\ Duluth, MN 55804, USA
}

Received 18 February 2004; received in revised form 17 May 2004; accepted 21 May 2004

\begin{abstract}
Evaluation of population-level impacts is critical to credible ecological risk assessments. In this study, a predictive model was developed to translate changes in fecundity of the fathead minnow (Pimephales promelas) in a short-term laboratory toxicity test to alterations in population growth rate. The model uniquely combines a Leslie population projection matrix and the logistic equation. Application of the model requires only a life table for the organism of interest, a measure of carrying capacity for the given population, and an estimation of the effect of a stressor on vital rates. The model was applied to investigate population dynamics for fathead minnow exposed to the androgen receptor agonist $17 \beta$-trenbolone. Organismal-level responses for fathead minnows exposed to varying levels of $17 \beta$-trenbolone were used to determine projected alterations in a population existing in a small body of water containing varying concentrations of the androgen. Fathead minnow populations occurring at carrying capacity and subsequently exposed to $0.027 \mu \mathrm{g} / \mathrm{L}$ of $17 \beta$-trenbolone exhibited a $51 \%$ projected decrease in average population size after 2 years of exposure. Populations at carrying capacity exposed to concentrations of $17 \beta$-trenbolone $\geqslant 0.266 \mu \mathrm{g} / \mathrm{L}$ exhibited a $93 \%$ projected decrease in average population size after 2 years of exposure. Overall, fathead minnow populations exposed to continued concentrations of $17 \beta$-trenbolone equal to or greater than $0.027 \mu \mathrm{g} / \mathrm{L}$ were projected to have average equilibrium population sizes that approached zero.

Published by Elsevier Inc.
\end{abstract}

Keywords: 17 $\beta$-Trenbolone; Endocrine disruptor; Fathead minnow; Leslie matrix; Logistic equation; Population projection

\section{Introduction}

Assessment of the ecological risk of chemical stressors to nonendangered species generally focuses on possible alterations in population dynamics, as opposed to effects at the level of the individual (Suter, 1993; US Environmental Protection Agency, 1998). This type of analysis ideally uses data concerning survival and reproductive capacity/success from long-term chronic toxicity tests. Unfortunately, due to the expense and complexity of these tests, it is uncommon that chronic

*Corresponding author. Fax: + 1-734-692-7603.

E-mail address: miller.davidh@epa.gov (D.H. Miller). toxicity data are available to directly forecast the likely effects of a chemical on a population of interest. It is more common to rely on abbreviated tests to generate vital rate data to provide input to population models for prediction of potential effects. One example of such a test is the short-term fathead minnow (Pimephales promelas) reproduction assay developed by Ankley et al. (2001) for identifying and assessing effects of endocrinedisrupting chemicals (EDCs). That assay features the collection of both data reflective of toxic mechanism/ mode of action and information suitable for predicting alterations in population dynamics (e.g., survival, fecundity, fertility). For this type of information to be useful, credible species-specific model constructs are 
needed to make linkages between responses at the individual level and those in populations.

In the present study, we developed a conceptual framework for population risk assessment based on data derived from the abbreviated fathead minnow reproduction assay. The procedure utilizes a model that requires a minimum number of parameters to be estimated from field data and that is composed of a combination of a Leslie population projection matrix and the logistic equation. In this study, the modeling approach requires only a life table, an estimate of carrying capacity, and quantitative evaluation of how a stressor (chemical or nonchemical) affects vital rates at the individual (organismal) level. This modeling approach allows population-level assessments to be conducted for a given population existing in an area with an estimated carrying capacity and can be used in conjunction with habitat suitability analysis. Specifically, we apply this modeling construct to investigate risk to a fathead minnow population exposed to $17 \beta$-trenbolone, a highaffinity agonist of the vertebrate androgen receptor (Wilson et al., 2002; Ankley et al., 2003).

Trenbolone acetate is a synthetic steroid administered to cattle as a growth promoter. One excretory product of the trenbolone acetate is $17 \beta$-trenbolone, which is comparatively stable in animal waste (Schiffer et al., 2001). This stability creates the potential for exposure of aquatic animals through direct contact from discharge or runoff from feedlots and/or via fields fertilized using contaminated manure. Ankley et al. (2003) found that $17 \beta$-trenbolone was a potent androgen and reproductive toxicant in the fathead minnow, masculinizing females and reducing fecundity at a water concentration as low as $0.027 \mu \mathrm{g} / \mathrm{L}$. Orlando et al. (2004) documented that endocrine and reproductive systems of wild fathead minnow below a feedlot were adversely affected by feedlot effluent. In the present study, we utilize concentration-response data from the study of Ankley et al. (2003) to project population-level changes for a fathead minnow population exposed to varying concentrations of $17 \beta$-trenbolone.

\section{Materials and methods}

\subsection{Model development}

Leslie (1945) and Lewis (1942) developed a matrix model that projects population growth over time using fecundity and survival rates of individual age classes within the population. Using the equation

$n_{t+1}=M n_{t}$,

the vector of population age structure at time $t+1$ $\left(\boldsymbol{n}_{t+1}\right)$ is calculated from the product of the Leslie matrix and the vector of population age structure at time $t\left(\boldsymbol{n}_{t}\right)$. Using birth pulse survival probabilities, birth pulse fertilities, and a prebreeding census (Gotelli, 1998; Caswell, 2001), the Leslie matrix can be written as

$$
M=\begin{array}{lllll}
F_{1} & F_{2} & F_{3} & \ldots & F_{i=n} \\
S_{1} & 0 & 0 & \ldots & : \\
0 & S_{2} & 0 & \ldots & \\
: & : & : & & \\
0 & \ldots & & S_{i=n-1} & 0
\end{array},
$$

where $S_{i}$ is the survival from age $i$ at time $t$ to age $i+1$ at time $t+1$ and $F_{i}$ is the fertility of age group $i$. For a given Leslie matrix, the stable age distribution can be calculated by finding an eigenvector (right eigenvector) associated with the dominant eigenvalue of the matrix (Leslie, 1945). It was shown by Leslie (1945) that the matrix $\boldsymbol{M}$ in Eq. (2) resulted in exponential growth when the population was at stable age distribution. Both the total population and each age class within the population grow exponentially. The dominant eigenvalue of the Leslie matrix represents the finite rate of increase. Taking the natural $\log$ of the dominant eigenvalue of the Leslie matrix results in the intrinsic rate of increase, an estimate of the per capita rate of population increase associated with a population represented by the rates in the matrix. Leslie's (1945) matrix model is limited in application because it describes exponential growth. Density dependence is the phenomenon by which the values of vital rates including survivorship and fecundity depend upon the density of the population (Burgman et al., 1993). Within a population, density-dependent competition results from increased population size, and fecundity and survival rates will decrease or increase based upon the amount of food and resources available to organisms, making exponential growth unlikely.

The logistic equation is the most thoroughly studied model of density-dependent population dynamics (Burgman et al., 1993). The logistic equation has been used for analysis of population projection within multiple studies and is widely accepted as a model for density-dependent population growth (Maynard-Smith, 1968; Roughgarden, 1975; May, 1976; Whittaker and Goodman, 1979; Krebs, 1985; Strebel, 1985; Bayliss, 1989; Burgman et al., 1993; Gotelli, 1998).

Miller (2001) found that a simple density-dependent matrix model can be constructed by combining the Leslie projection matrix of Eq. (2) with a discrete time form of the logistic equation. Discrete time forms of the exponential and logistic equation can be written as (May, 1974)

$P_{t+1}=P_{t} \exp (r) P_{t}$

and

$P_{t+1}=P_{t} \exp \left(r-r P_{t} / K\right)$, 
where $P_{t}$ is the scalar population size at time $t, P_{t+1}$ is the scalar population size at time $t+1, r$ is the intrinsic rate of increase, and $K$ is the carrying capacity. Eq. (3) can be multiplied by $\exp \left(-r P_{t} / K\right)$ to obtain Eq. (4). Likewise, the Leslie matrix of Eq. (2) can be multiplied by $\exp \left(-r P_{t} / K\right)$ to describe logistic growth resulting in the equation

$n_{t+1}=\exp \left(-r P_{t} / K\right) M n_{t}$.

The matrix model of Eq. (5) exhibits stability characteristics at a stable age distribution exactly identical to the discrete time form of the logistic Eq. (4), as described by May (1974). The logistic matrix model of Eq. (5) requires no additional parameters to be estimated from field populations beyond that found in a combined life and fecundity table and an estimate of carrying capacity. Also, this model provides a simple link between life table parameters, the logistic growth equation, and Leslie's original projection matrix.

When applying to field populations whereby detailed information has been collected for the effect of density on individual age classes, Eq. (5) offers the versatility of replacing $\exp \left(-r P_{t} / K\right)$ with age-specific density-dependent functions; this could be accomplished in Eq. (5) by replacing $\exp (-r P t / K)$ with a diagonal matrix of agespecific density-dependent functions. Alternatively, when field data exists such that density-dependent functions could be precisely estimated for each vital rate within the matrix $M$, the Leslie matrix in Eq. (5) can then be separated into a matrix for births and a matrix for deaths (Goodman, 1969; Usher, 1969; Jensen, 1974, 1995), and separate density-dependent functions could be applied to each process. Although this approach is most realistic in theory, difficulty in parameter estimation related to each separate vital rate-specific densitydependent function will increase the uncertainty of model predictions.

To investigate the population-level effects resulting from exposure to a toxic chemical, Eq. (5) can be altered to

$n_{t+1}=\exp \left(-r P_{t} / K\right) M^{*} n_{t}$,

where $\boldsymbol{M}^{*}$ is the Leslie matrix containing vital rates (survivorship and fertility) that have been adjusted to include an age-specific percentage reduction in fecundity and/or survival rates over the time step $t$ resulting from an exposure. Thus, using Eq. (6), the effect of a chemical on population size can be investigated with respect to a population existing in a given geographic area with a given carrying capacity.

In analyzing the effect of environmental variability, the biology of the species should be used to guide exploration of the most variable life history traits and their corresponding parameters in the model. The model sensitivity to the most variable life history traits can be investigated by varying the parameters associated with these traits within the Leslie matrix over a range of values corresponding to that observed for the species. In this way, projections for average population size can then be calculated over the range of values of the most influential model parameter(s).

\subsection{Model application}

We predicted population dynamics for fathead minnows exposed to the androgenic growth promoter $17 \beta$-trenbolone. Concentration-response data at the individual level were taken from Ankley et al. (2003), who determined the effects of $17 \beta$-trenbolone on reproduction in the fathead minnow over 21 days at water concentrations ranging from 0.0015 to about $41 \mu \mathrm{g} / \mathrm{L}$. In that study, adult survival rate remained unchanged over varying exposure values, but fecundity of the fish was reduced at test concentrations $\geqslant 0.027 \mu \mathrm{g} /$ L (Table 1). Life history characteristics of the fathead minnow were collected and analyzed from multiple studies (Westman, 1938; Zischke et al., 1983; Duda, 1989; Gleason and Nacci, 2001). Fathead minnows breed annually within a breeding period that lasts 2-3 months. Female fathead minnows mature at age 1 year and reproduce annually with reproductive output that varies with age (Westman, 1938; Zischke et al., 1983; Duda, 1989; Gleason and Nacci, 2001). Within the present study, we chose to apply a density-dependent logistic matrix model based upon age structure. Such a model is appropriate for use in analyzing a fathead minnow population whereby a stressor such as $17 \beta$ trenbolone is affecting reproductive output that varies with age. However, it is important to point out that a Leslie matrix structured by size classes as opposed to age classes may be appropriate for demonstrating a stressor's effect on fish growth rate. The density-dependent logistic matrix model as derived above could be used with either a size-class-based or an age-class-based

Table 1

Effects on female fathead minnow fecundity of exposure to varying concentrations of $17 \beta$-trenbolone (data from Ankley et al., 2003)

\begin{tabular}{lc}
\hline $\begin{array}{l}17 \beta \text {-trenbolone } \\
\text { concentration }(\mu \mathrm{g} / \mathrm{L})\end{array}$ & $\begin{array}{l}\text { Decrease in } \\
\text { fecundity }(\% \text { change })^{\mathrm{a}}\end{array}$ \\
\hline 0.0015 & $0^{\mathrm{b}}$ \\
0.027 & 50.1 \\
0.266 & 100 \\
4.35 & 100 \\
40.6 & 100 \\
\hline
\end{tabular}

${ }^{\text {a }}$ Values for decrease in fecundity were calculated by regressing cumulative egg production versus time for fathead minnow exposed at a constant concentration. The $R^{2}$ value for the regressions ranged from 0.850 to 0.933 .

${ }^{\mathrm{b}}$ No significant difference was found between fecundity of female fathead minnow exposed to $0.0015 \mu \mathrm{g} / \mathrm{L}$ of $17 \beta$-trenbolone compared to the control group. 
Table 2

Life table for the fathead minnow vital rates derived from populations (Westman, 1938; Zischke et al., 1983; Duda, 1989; Gleason and Nacci, 2001)

\begin{tabular}{llr}
\hline Age (years) & Survival (per year) & Fecundity (eggs/year) \\
\hline 0 & 1 & 0 \\
1 & 0.001 & 750 \\
2 & 0.00039 & 1500 \\
3 & 0.0001521 & 3000 \\
4 & 0 & N/A \\
\hline
\end{tabular}

$\mathrm{M}_{\text {fathead minnow }}=\left[\begin{array}{ccc}0.75 & 1.5 & 3 \\ 0.39 & 0 & 0 \\ 0 & 0.39 & 0\end{array}\right]$

Fig. 1. Leslie matrix for the fathead minnow derived from field studies (Westman, 1938; Zischke et al., 1983; Duda, 1989; Gleason and Nacci, 2001) and developed using birth pulse survival and fertility rates and a prebreeding census (Gotelli, 1998; Caswell, 2001).

Leslie matrix. Age-specific vital rates were estimated by Gleason and Nacci (2001) for the fathead minnow based upon survival and fecundity data taken from studies of populations (Westman, 1938; Zischke et al., 1983; Duda, 1989). We constructed a life table (Table 2) and a Leslie matrix model (Fig. 1), using birth pulse fertility values and a prebreeding census (Leslie, 1945; Caswell, 2001), for the fathead minnow based upon the age-specific survival and fecundity rates estimated by Gleason and Nacci (2001). In using birth pulse fertilities and a prebreeding census with an annual time step, the $F_{i}$ values in Eq. (2) are calculated as the product of survival from birth to age 1 year and the reproductive output of an individual upon reaching its $i$ th birthday (Caswell, 2001). Birth pulse fertility values were used because the fathead minnow has an annual breeding season lasting 2-3 months (Westman, 1938), and a prebreeding census was chosen as it would relieve the need to estimate total eggs within the water body when comparing the model to field samples.

We examined the population-level effects resulting from loss in fecundity at various exposure concentrations for a population of fathead minnow existing at carrying capacity in a small body of water typical of what might be found adjacent to a feedlot (Orlando et al., 2004). In the case of fish which exhibit indeterminate growth, carrying capacity may be more accurately defined with regard to biomass (Diana, 2004). But since fathead minnows undergo "scramble competition" leading to equal sharing of resources (Waller et al., 1971), it is acceptable to define carrying capacity with regard to fish numbers. This is borne out in historical field data, which show that fathead minnow have been recorded at high population densities in standing bodies of water ranging from 5.19 to $6.14 \mathrm{fish} / \mathrm{m}^{3}$ (O'Neil, 1979). Using a density estimate of $5.665 \mathrm{fish} / \mathrm{m}^{3}$ for a fathead minnow population at carrying capacity (the midpoint of the range cited by O'Neil (1979), a small body of water containing $1000 \mathrm{~m}^{3}$ of habitat would contain approximately 5665 fathead minnows. Because we were investigating the effect of $17 \beta$-trenbolone on population size for a population of fathead minnow existing at carrying capacity and had assumed logistic population growth, all of the model simulations were initiated with the population at the stable age distribution as calculated from the Leslie matrix. Stable age distribution was determined from the Leslie matrix by finding an eigenvector associated with the dominant eigenvalue of the matrix and rescaling the eigenvector (Caswell, 2001). Using this approach, a population of 5665 fathead minnows at stable age distribution would consist of 4178 age class 1 fathead minnows, 1163 age class 2 fathead minnows, and 324 age class 3 fathead minnows at the beginning of the first time step.

We used the density-dependent logistic matrix model of Eq. (6) to examine the impact on fathead minnow population size resulting from exposure to three concentrations of $17 \beta$-trenbolone of $\geqslant 0.266,0.027$, and $\leqslant 0.0015 \mu \mathrm{g} / \mathrm{L}$. For each simulation, a population of fathead minnow initially existed at a carrying capacity of 5665 and was subsequently exposed to a given amount of $17 \beta$-trenbolone. For each simulation, the value of population size was projected over time, and the equilibrium population size was determined.

Among fathead minnow populations, fecundity and survival of age 0 year fish to age 1 year is highly variable (Westman, 1938; Duda, 1989; Grant and Tonn, 2002) and influential on population growth. Within our model, the fecundity of breeding fish and the survival of age 0 year fish to age class 1 is represented by the fertility parameters of the model ( $F_{i}$ terms) as the Leslie matrix uses a prebreeding census (Caswell, 2001). To investigate sensitivity of the model projections to fertility rate, we varied the fertility parameters in the matrix from $80 \%$ to $120 \%$ of their mean values in increments of $10 \%$. Based upon studies by Westman (1938), Duda (1989), and Grant and Tonn (2002), this range of values is representative of what one might expect in a real world population. Westman (1938) sampled 10 female fathead minnow and found that their egg production differed by less than $10 \%$ of the mean value of eggs produced for all 10 females. Duda (1989) found that fathead minnow fry survival had a standard deviation of $10 \%$ of the mean fry survival rate. Grant and Tonn (2002) found that total eggs laid in the spawning season per female fathead minnow and total number of eggs hatched in the spawning season per female fathead minnow had standard errors of the mean 
that were approximately $10-20 \%$ of the respective mean values. This approach to investigating sensitivity of model projections to variability in fertility rate was applied to examine the impact on fathead minnow population size resulting from exposure of $0.027 \mu \mathrm{g} / \mathrm{L}$ of $17 \beta$-trenbolone. Sensitivity of model projections to fertility rates was not investigated for exposure to $17 \beta$ trenbolone concentrations $\leqslant 0.0015 \mu \mathrm{g} / \mathrm{L}$, as exposures at this level had no negative effect on fecundity (Ankley et al., 2003), and thus a fathead minnow population existing at carrying capacity would, on average, be expected to remain near carrying capacity. In addition, sensitivity of model projections to fertility rate was not investigated for exposure to $17 \beta$-trenbolone concentrations $\geqslant 0.266 \mu \mathrm{g} / \mathrm{L}$, as exposures at this level completely inhibited spawning during a 21-day test (Ankley et al., 2001, 2003).

\section{Results}

The Leslie matrix for the fathead minnow (Fig. 1) derived from field studies by Westman (1938), Zischke et al. (1983), Duda (1989), and Gleason and Nacci (2001) yielded an intrinsic rate of increase equal to 0.337 . Exposure to some levels of $17 \beta$-trenbolone compromised the fecundity of fathead minnows (see Table 1), and thus the annual fertility rates of the different age classes within the Leslie matrix were adjusted accordingly to account for the exposure within model projections. The projected trend in population growth for a fathead minnow population existing at a carrying capacity of 5665 and subsequently exposed to varying levels of $17 \beta$-trenbolone of $\geqslant 0.266,0.027$, and $\leqslant 0.0015 \mu \mathrm{g} / \mathrm{L}$ was calculated from Eq. (6) (Fig. 2). Exposure to concentrations of $17 \beta$-trenbolone equal to

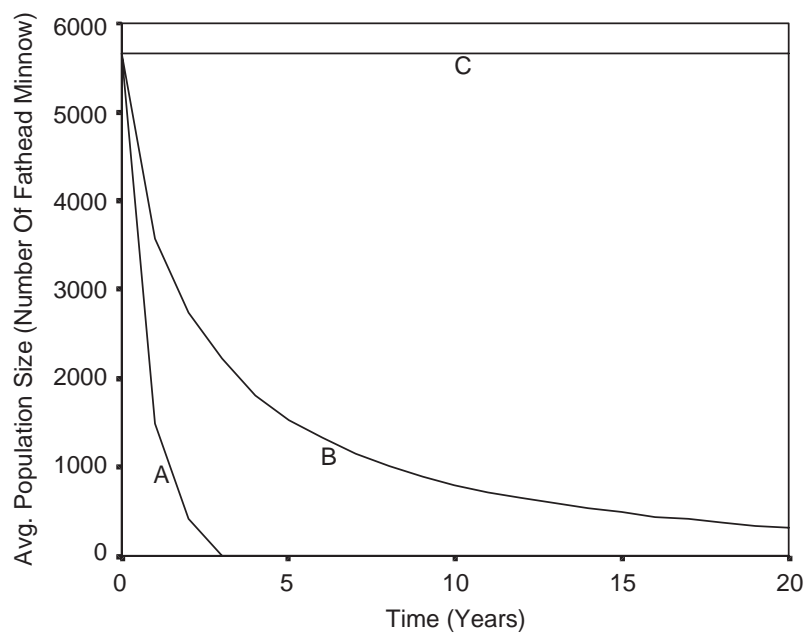

Fig. 2. Population projection for a fathead minnow population existing at a carrying capacity of 5665 and subsequently exposed to varying levels of $17 \beta$-trenbolone. Three exposure concentrations were evaluated: (A) $\geqslant 0.266 \mu \mathrm{g} / \mathrm{L},(B)=0.027 \mu \mathrm{g} / \mathrm{L}$, and $(C) \leqslant 0.0015 \mu \mathrm{g} / \mathrm{L}$. or in excess of $0.027 \mu \mathrm{g} / \mathrm{L}$ resulted in a population decline over time. Exposure to concentrations of $17 \beta$ trenbolone $\geqslant 0.266 \mu \mathrm{g} / \mathrm{L}$ completely inhibited fathead minnow spawning and the projected population trend resulted in an approximate $74 \%$ decrease in average population size (1488 fathead minnows remaining in the population) after 1 year and a $93 \%$ reduction in average population size (415 fathead minnows remaining in the population) after 2 years of exposure. Due to a lack of recruitment, the population was extinct after 3 years. In comparison, a fathead minnow population at a carrying capacity of 5665 individuals and subsequently exposed to a concentration of $0.027 \mu \mathrm{g} / \mathrm{L} 17 \beta$-trenbolone resulted in an approximate $37 \%$ decrease in average population size (3573 fathead minnows remaining in the population) after 1 year and a $51 \%$ reduction in population size (2751 fathead minnows remaining in the population) after 2 years. Exposure to $0.027 \mu \mathrm{g} / \mathrm{L}$ $17 \beta$-trenbolone resulted in a population size at equilibrium that approaches 0 , requiring only 13 years for the population to decrease to an average size of approximately $10 \%$ of carrying capacity (587 individuals). A fathead minnow population at carrying capacity, exposed to a concentration of $17 \beta$-trenbolone less than or equal to $0.0015 \mu \mathrm{g} / \mathrm{L}$, would be expected to remain at carrying capacity since vital rates remained unchanged at this concentration (Ankley et al., 2003).

Model projections for a fathead minnow population at a carrying capacity of 5665 , subsequently exposed to $0.027 \mu \mathrm{g} / \mathrm{L} 17 \beta$-trenbolone, were examined with respect to variability in fertility rates. In this analysis, fertility rates were varied from $80 \%$ to $120 \%$ of their respective mean values in increments of $10 \%$ (Table 3). Under favorable conditions that would foster higher fertility rates (fertility values set at $120 \%$ of their respective mean values within the Leslie matrix), exposure to $0.027 \mu \mathrm{g} 17 \beta$-trenbolone $/ \mathrm{L}$ resulted in an approximate $30 \%$ decrease in average population size (3990 fathead minnows remaining in the population) after 1 year and a $42 \%$ reduction in average population size (3298 fathead minnows remaining in the population) after 2 years of exposure. In comparison, for populations existing under less favorable conditions (fertility values set at $80 \%$ of their respective mean values within the Leslie matrix), exposure to $0.027 \mu \mathrm{g} / \mathrm{L}$ of the androgen resulted in an approximate $44 \%$ decrease in average population size (3156 fathead minnows remaining in the population) after 1 year and a $61 \%$ reduction in population size (2228 fathead minnows remaining in the population) after 2 years.

\section{Discussion}

Overall, our results indicate that fathead minnow populations exposed to continuous concentrations of 
Table 3

Sensitivity of model projections to fertility rates within the Leslie matrix

\begin{tabular}{|c|c|c|c|c|c|}
\hline & $\begin{array}{l}\text { Fertility rates } \\
\text { set to } 80 \% \\
\text { of matrix values }\end{array}$ & $\begin{array}{l}\text { Fertility rates } \\
\text { set to } 90 \% \\
\text { of matrix values }\end{array}$ & $\begin{array}{l}\text { Fertility rates } \\
\text { unchanged }\end{array}$ & $\begin{array}{l}\text { Fertility rates } \\
\text { set to } 110 \% \\
\text { of matrix values }\end{array}$ & $\begin{array}{l}\text { Fertility rates } \\
\text { set to } 120 \% \\
\text { of matrix values }\end{array}$ \\
\hline Population size after 1 year of exposure & 3156 & 3364 & 3573 & 3781 & 3990 \\
\hline Population size after 2 years of exposure & 2228 & 2488 & 2751 & 3021 & 3298 \\
\hline
\end{tabular}

Fertility rates were varied from $80 \%$ to $120 \%$ of their values found within the Leslie matrix, and projections for a fathead minnow population existing at carrying capacity of 5665 , exposed to $0.027 \mu \mathrm{g} 17 \beta$-trenbolone/L, was calculated for 1 and 2 years of exposure.

Table 4

Sensitivity of model projections to the estimate of carrying capacity

\begin{tabular}{llllll}
\hline & $\begin{array}{l}\text { Carrying capacity } \\
\text { set to 4715 }\end{array}$ & $\begin{array}{l}\text { Carrying capacity } \\
\text { set to 5190 }\end{array}$ & $\begin{array}{l}\text { Carrying capacity } \\
\text { set to 5665 }\end{array}$ & $\begin{array}{l}\text { Carrying capacity } \\
\text { set to 6140 }\end{array}$ & $\begin{array}{l}\text { Carrying capacity } \\
\text { set to 6615 }\end{array}$ \\
\hline Population size after 1 year of exposure & 3322 & 3655 & 3990 & 4323 & 4657 \\
Population size after 5 years of exposure & 1853 & 1858 & 2028 & 2197 & 2599 \\
Population size after 10 years of exposure & 1278 & 1334 & 1456 & 1579 & 1793 \\
Population size after 20 years of exposure & 880 & 945 & 1032 & 1119 & 1235 \\
\hline
\end{tabular}

Carrying capacity was varied from 4715 to 6615 fathead minnows, and projections for a fathead minnow population existing at carrying capacity and exposed to $0.027 \mu \mathrm{g} 17 \beta$-trenbolone/ $\mathrm{L}$ were calculated for $1,5,10$, and 20 years of exposure. The range of $4715-6615$ fathead minnows is twice the range of fathead minnow density reported by O'Neil (1979). Each model simulation was initiated with the population at the stable age distribution as calculated from the Leslie matrix.

$17 \beta$-trenbolone $\geqslant 0.027 \mu \mathrm{g} / \mathrm{L}$ would exhibit large population losses within a 2-year period and risk future extinction. Unfortunately, there currently are no published data concerning $17 \beta$-trenbolone concentrations in aquatic systems. However, some research related to the fate of $17 \beta$ - and $17 \alpha$-trenbolone in the environment has been conducted. Schiffer et al. (2001) demonstrated that the half-life of $17 \beta$-trenbolone in liquid manure was approximately 260 days and that trenbolone residues were detectable in soil to which the manure had been applied for as many as 8 weeks after application. This suggests the potential for exposure of aquatic animals to trenbolone via direct discharge and runoff associated with feedlots (Makynen et al., 2002; Orlando et al., 2004).

Although there are no published data concerning direct measurement of trenbolone in waters associated with active feedlots, there is evidence for the presence of androgenic chemicals in water bodies and/or discharges from beef feedlots in the USA. For example, studies with drain water samples from a feedlot in Ohio have indicated the presence of chemicals which act as androgen receptor agonists in vitro (Makynen et al., 2002). More recently, Orlando et al. (2004) demonstrated the occurrence of androgenic activity within a small water body adjoining a feedlot in Nebraska resulting in adverse effects to the development and reproductive endocrinology of the exposed fathead minnows. Future studies at these sites are needed to confirm the occurrence of trenbolone acetate metabolites and to ascertain the degree to which they might be responsible for observed androgenic activity. This type of information is critical to supporting a full assessment of the potential risk of trenbolone to fish and other wildlife.

In our analysis, we have estimated carrying capacity based upon measurement of a maximum density of fathead minnows found in a small water body. To verify this estimate, long-term monitoring of the water body would be necessary to demonstrate a relatively stable population density. Alternatively, detailed habitat suitability analysis could be used to determine an estimate of carrying capacity based upon variables measured within the landscape (Mladenoff et al., 1995, 1997). To demonstrate the sensitivity of model projections to carrying capacity, we used Eq. (6) to project the trend in population growth for a fathead minnow population existing at varying values of carrying capacity (varying values of $K$ in Eq. (6)) and subsequently exposed to $17 \beta$ trenbolone equal to $0.027 \mu \mathrm{g} / \mathrm{L}$ (Table 4). The value of carrying capacity was varied from 4715 to 6615 fathead minnow, consistent with a range of maximum densities that is twice as wide as those reported by O'Neil (1979). Each model simulation was initiated with the population at the stable age distribution as calculated from the Leslie matrix. When the population size is near carrying capacity, the effect of carrying capacity on model projections will be the strongest, as demonstrated in Table 4 by the greatest deviations between projections occurring near carrying capacity. As supported by Table 4 , a precise estimate of carrying capacity can decrease the uncertainty of model projections.

Variability in laboratory data should also be considered in evaluating model projections. The response to 
exposure to a given chemical stressor at the level of the individual will have a variability associated with it that can be quantified and used within the model of Eq. (6) to bound model projections at the population-level with respect to variability in response to the stressor at the individual level. As an example, we used laboratory results from Ankley et al. (2003) and regression analysis (regressing cumulative egg production versus time) to estimate a $95 \%$ confidence interval for the decrease in female fathead minnow fecundity resulting from exposure to $0.027 \mu \mathrm{g} / \mathrm{L}$ of $17 \beta$-trenbolone. The $95 \%$ confidence interval for the decrease in female fathead minnow fecundity was determined to be $41.3-60.5 \%$, as compared to $50.1 \%$ listed in Table 1 . We demonstrate how this confidence interval can be used to bound our model projection for population response to exposure at $0.027 \mu \mathrm{g} / \mathrm{L} 17 \beta$-trenbolone relative to the variability in individual response to exposure (Fig. 3).

The matrix model presented here analyzes changes in population growth resulting from changes to vital rates. This investigation, based upon reproductive success measures and survival measures, still leaves some other long-term effects unassessed. Long-term immune function and salt and water balance (osmotic stress) are not assessed within the current model. A comprehensive analysis of a particular feedlot could ideally include measurements of runoff flows for salts. Migration is also not accounted for in the current model as a closed system was assumed. However, it is possible to use the modeling approach described here to assess migration of organisms between closed systems. Within such an approach, using Eq. (6), a vector representing the distribution of migrants (or immigrants) among age

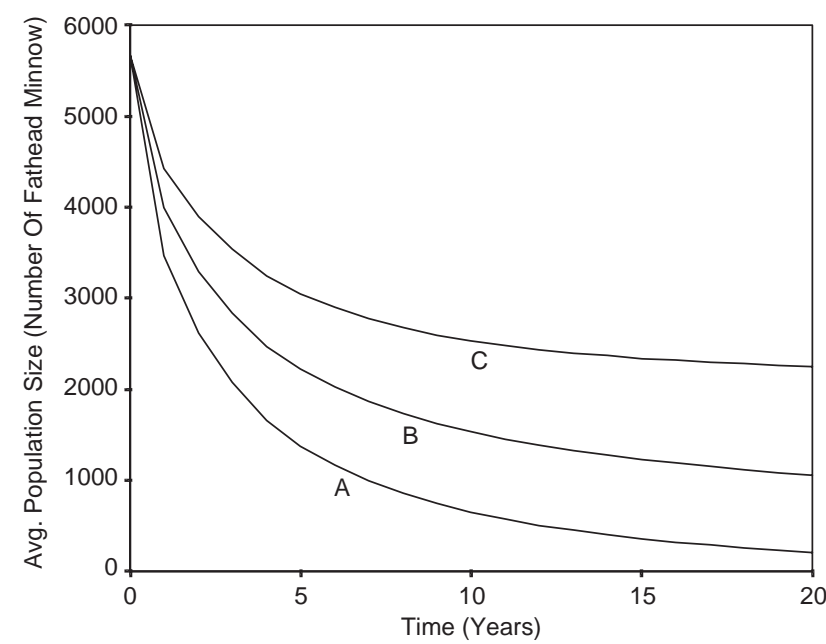

Fig. 3. Population projection for a fathead minnow population existing at a carrying capacity of 5665 and subsequently exposed to $0.027 \mu \mathrm{g} / \mathrm{L}$ of $17 \beta$-trenbolone. The percentage reduction in fecundity as a result of exposure was varied: (A) $41.3 \%$ reduction (lower confidence limit), (B) $=50.1 \%$ reduction, and (C) $60.5 \%$ reduction (upper confidence limit). classes would be added to (or subtracted from) the population total at each time step.

EDCs can adversely affect animals in different ways, causing direct and indirect effects at multiple levels of biological organization, including alterations in circulating sex steroids, delayed/abnormal sexual differentiation, behavioral alterations, and changes in gamete quality that result in decreased fecundity or fertility (Bryan et al., 1986; Bright and Ellis, 1990; Gilbertson et al., 1991; Sharp and Skakkeback, 1993; Guillette et al., 1994; Munkittrick et al., 1994; Orlando et al., 2004). Understanding population-level responses to chemical stressors such as EDCs is key to the ecological risk assessment process. Yet, the type of effects data available for assessments, generally, is collected at the level of the individual. Realistic predictive models are therefore critical to translating data from individuals to populations. In the present study, we use data generated from a short-term reproduction assay with the fathead minnow (Ankley et al., 2001) to make inferences about likely impacts of an androgenic chemical, $17 \beta$-trenbolone, on dynamics of a closed fathead minnow population. Alternatively, a fish full-life-cycle study could be used to investigate the ecotoxicological effects of a given chemical, with subsequent population-level modeling. As an example, Lange et al. (2001) examined the effects of the synthetic estrogen $17 \alpha$-ethinylestradiol on the life cycle of the fathead minnow, and Grist et al. (2003) used the results of the Lange et al. (2001) analysis to estimate effects of $17 \alpha$-ethinylestradiol on populations of the fathead minnow. Grist et al. (2003) constructed a Leslie matrix for the fathead minnow to examine change in intrinsic rate of population growth obtained from changes in exposure concentration of $17 \alpha$-ethinylestradiol. The model construct that we developed for this study (1) focused upon impact of a chemical to vital rates and (2) estimated density-dependent population trajectories upon exposure to the chemical with respect to time for a geographically isolated population composed of multiple age classes. Although this particular analysis evaluated a specific EDC, the basic modeling approach could easily be expanded to include other chemical and nonchemical stressors in more complex habitats. We used the logistic matrix model of Eq. (6) in its simplest form because we did not have sufficient field data available to support the creation of precise functions to describe how each individual age class responds to increased density or to describe how the vital rates of each individual age class respond separately to density-dependent population growth for the fathead minnow. With the addition of more detailed site-specific field studies, we could incorporate more complex functions to precisely describe how age classes or how vital rates within the density-dependent matrix model would vary with density. As an example of the use of detailed site-specific data to generate precise vital 
rate-specific density-dependent functions, Brown et al. (2003) demonstrated that site-specific life history data for brown trout (Salvelinus fontinalis) from Hunt Creek, Michigan and fathead minnow from Horseshoe Lake, Minnesota could be used to make predictions about the effects of nonylphenol and methoxychlor on population dynamics using a delay differential equation model with a 1 day time step. In 1995, the Office of Research and Development of the US Environmental Protection Agency sponsored a workshop that focused on a variety of issues central to the development of a research strategy for assessing ecological effects of endocrine disruptors (Ankley et al., 1997). Within that forum, it was decided that researchers should proceed from firstorder models to higher-order models. Accounting for density-dependent population growth is a difficulty facing many ecotoxicological risk assessments. In its simplest form, our approach will fill the need for accounting for density dependence as a screening-level model. To improve upon the screening-level results, sitespecific intensive field study could provide subsequent details allowing further analysis, whereby formulation of precise density-dependent functions for each age class or for each vital rate of each age class within the Leslie matrix could be constructed.

\section{Acknowledgments}

We thank Kathleen Jensen for assembling the data sets necessary for completion of the present study. Also, we thank Mary Ann Starus, Tim Gleason, Anett Trebitz, Matthew Mitro, Ronald Rossmann, and Russell G. Kreis, Jr. for providing a valuable review of the manuscript. The information in this document has been funded wholly by the US Environmental Protection Agency. It has been subjected to review by the National Health and Environmental Effects Research Laboratory and approved for publication. Approval does not signify that the contents reflect the views of the Agency, nor does mention of trade names or commercial products constitute endorsement or recommendation for use.

\section{References}

Ankley, G.T., Johnson, R.D., Detenbeck, N.E., Toth, G., Folmar, L.C., 1997. Development of a research strategy for assessing the ecological risk of endocrine disruptors. Rev. Toxicol. 1, 71-106.

Ankley, G.T., Jensen, K.M., Kahl, M.D., Korte, J.L., Makynen, E.A., 2001. Description and evaluation of a short-term reproductive test with the fathead minnow (Pimephalas promelas). Environ. Toxicol. Chem. 20, 1276-1290.

Ankley, G.T., Jensen, K.M., Makynen, E.A., Kahl, M.D., Korte, J.J., Hornung, M.W., Henry, T.R., Denny, J.S., Leino, R.L., Wilson, V.S., Cardon, M.D., Hartig, P.C., Gray, L.E., 2003. Effects of the androgenic growth promoter $17 \beta$-trenbolone on fecundity and reproductive endocrinology of the fathead minnow. Environ. Toxicol. Chem. 22, 1350-1360.

Bayliss, P., 1989. Population dynamics of magpie geese in relation to rainfall and density: implication for harvest models in a fluctuating environment. J. Appl. Ecol. 26, 913-924.

Bright, D.A., Ellis, D.V., 1990. A comparative survey of imposex in the northeast Pacific gastropods (Prosobranchia) related to tributyltin contamination, and choice of a suitable indicator. Can. J. Zool. 68, 1915-1924.

Brown, A.R., Riddle, A.M., Cunningham, N.L., Kedwards, T.J., Shillabeer, N., Hutchinson, T.H., 2003. Predicting the effects of endocrine disrupting chemicals on fish populations. Hum. Ecol. Risk Assess. 9, 761-788.

Bryan, G.W., Gibbs, P.E., Hummerstone, L.G., Burt, G.R., 1986. The decline of the gastropod Nucella lapillus around southwest England: evidence for the effect of tributyltin from antifouling paints. J. Mar. Biol. Assoc. UK 66, 611-640.

Burgman, M.A., Ferson, S., Akcakaya, H.R., 1993. Risk Assessment in Conservation Biology. Chapman \& Hall, London.

Caswell, H., 2001. Matrix Population Models. Sinauer Associates, Inc., Sunderland, MA, USA.

Diana, J.S., 2004. Biology and Ecology of Fishes 2nd Edition. Cooper Publishing Group., Carmel, IN, USA.

Duda, S.W., 1989. Controlled spawning of laboratory reared fathead minnows (Pimephales promelas) and effect of different diets on survival and growth of the fry. M.S. Thesis, State University of New York, Brockport, NY, USA.

Gilbertson, M., Kubiak, T., Ludwig, J., Fox, G., 1991. Great Lakes embryo mortality, edema, and deformities syndrome (GLEMEDS) in colonial fish-eating waterbirds: similarity to chick edema disease. J. Toxicol. Environ. Health 33, 455-520.

Gleason, T., Nacci, D.E., 2001. Risks of endocrine-disrupting compounds to wildlife: extrapolating from effects on individuals to population response. Hum. Ecol. Risk Assess. 7, $1027-1042$.

Goodman, L.A., 1969. The analysis of population growth when the birth and death rates depend on several factors. Biometrics 25 , 659-681.

Gotelli, N.J., 1998. A Primer of Ecology. Sinauer Associates, Inc., Sunderland, MA, USA.

Grant, S.C.H., Tonn, W.M., 2002. Effects of nutrient enrichment on recruitment of age-0 fathead minnows (Pimephales promelas): potential impacts of environmental change on the boreal plains. Can. J. Fish. Aquat. Sci. 59, 759-767.

Grist, E.P.M., Wells, N.C., Whitehouse, P., Brighty, G., Crane, M., 2003. Estimating the effects of $17 \alpha$-ethinylestradiol on populations of the fathead minnow Pimephales promelas: are conventional toxicological endpoints adequate? Environ. Sci. Technol. 37, 1609-1616.

Guillette, L.J., Gross, T.S., Masson, G.R., Matter, J.M., Percival, H.F., Woodward, H.R., 1994. Developmental abnormalities of the gonad and abnormal sex hormone concentrations in juvenile alligators from contaminated and controlled lakes in Florida. Environ. Health Perspect. 102, 680-688.

Jensen, A.L., 1974. Leslie matrix models for fisheries studies. Biometrics 30, 547-551.

Jensen, A.L., 1995. Simple density-dependent matrix model for population projection. Ecol. Model. 77, 43-48.

Krebs, C.J., 1985. Ecology: The Experimental Analysis of Distribution and Abundance. Harper \& Row, New York, NY, USA.

Lange, R., Hutchinson, T.H., Croudace, C.P., Siegmund, F., Schweinfurth, H., Hampe, P., Panter, G.H., Sumpter, J.P., 2001. Effects of the synthetic estrogen $17 \alpha$-ethinylestradiol on the lifecycle of the fathead minnow (Pimephales promelas). Environ. Toxicol. Chem. 20 (6), 1216-1227. 
Leslie, P.H., 1945. On the use of matrices in certain population mathematics. Biometrika 35, 183-212.

Lewis, E.G., 1942. On the generation and growth of a population, Sankhya. Indian J. Stat. 6, 93-96.

Makynen, E.A., Durhan, E.J., Lambright, C.R., Wilson, V.S., Gray, L.E., Lazorchak, J.M., Smith, M.E., Weichman, B.E., Ankley, G.T., 2002. Contribution of the growth promoter trenbolone to androgenic activity of a feedlot discharge. 23rd Annual Meeting of the Society of Environmental Toxicology and Chemistry, Salt Lake City, Utah, USA, November 16-20, p. 266, Abstract.

May, R.M., 1974. Biological populations with nonoverlapping generations: stable points, stable cycles, and chaos. Science 186, 645-647.

May, R.M., 1976. Theoretical Ecology. Blackwell, Oxford.

Maynard-Smith, J., 1968. Mathematical Ideas in Biology. Cambridge University Press, Cambridge.

Miller, D.H., 2001. Examining gray wolf projection, control, and viability using density-dependent logistic matrix models. Ph. D. Thesis, University of Michigan, Ann Arbor, MI, USA.

Mladenoff, D.J., Sickley, T.A., Haight, R.G., Wydeven, A.P., 1995. A regional landscape analysis and prediction of favorable gray wolf habitat in the northern Great Lakes region. Conserv. Biol. 9, 279-294.

Mladenoff, D.J., Haight, R.G., Sickley, T.A., Wydeven, A.P., 1997. Causes and implications of species restoration in altered ecosystems. Bioscience 47 (1), 21-31.

Munkittrick, K.R., Van Der Kraak, G.J., McMaster, M.E., Portt, C.B., Van Den Hueval, M.R., Servos, M.R., 1994. Survey of receiving-water environmental impacts associated with discharges from pulp mills. 2. Gonad size, liver size, hepatic EROD activity, and plasma sex steroid levels in white sucker. Environ. Toxicol. Chem. 13, 1089-1101.

O'Neil, J., 1979. Fisheries survey of the Beaver Creek Diversion System, 1978. R. L. \& L. Environmental Services, Syncrude Canada, Environmental Research Monograph 1979-3, 76pp.

Orlando, E.F., Kolok, A.S., Binzcik, G.A., Gates, J.L., Horton, M.K., Lambright, C.S., Gray, E.L., Soto, A.M., Guillette, L.J., 2004.
Endocrine-disrupting effects of cattle feedlot effluent on an aquatic sentinel species, the fathead minnow. Environ. Health Perspect. 112 (3), 353-358.

Roughgarden, J., 1975. A simple model for population dynamics in stochastic environments. Am. Nat. 109, 713-736.

Schiffer, B., Daxenberger, A., Meyer, K., Meyer, H.D., 2001. The fate of trenbolone acetate and melengestrol acetate after application as growth promotors in cattle: environmental studies. Environ. Health Perspect. 109, 1145-1151.

Sharp, R.M., Skakkeback, N.E., 1993. Are estrogens involved in falling sperm count and disorders of the male reproductive tract? Lancet 341, 1392-1395.

Strebel, D.E., 1985. Environmental fluctuations and extinction-single species. Theor. Pop. Biol. 27, 1-26.

Suter II, G.W., 1993. Ecological Risk Assessment. Lewis Publishers, Boca Raton, FL, USA.

US Environmental Protection Agency, 1998. Guidelines for Ecological Risk Assessment. EPA/630/R-95/022F, Risk Assessment Forum, Washington, DC, USA.

Usher, M.B., 1969. A matrix model for forest management. Biometrics 25, 309-315.

Waller, W.T., Dahlberg, M.L., Sparks, R.E., Cairns Jr., J., 1971. A computer simulation of the effects of superimposed mortality due to pollutants on populations of fathead minnows (Pimephales promelas). J. Fish. Res. Board Can. 28, 1107-1112.

Westman, T.H., 1938. Studies on the reproduction and growth of the fathead minnow. Copeia 2, 57-61.

Whittaker, R.H., Goodman, D., 1979. Classifying species according to their demographic strategy. I. Population fluctuations and environmental heterogeneity. Am. Nat. 113, 185-200.

Wilson, V.S., Lambright, C., Ostby, J., Gray, L.E., 2002. In vitro and in vivo effects of $17 \beta$-trenbolone: a feedlot effluent contaminant. Toxicol. Sci. 70, 202-211.

Zischke, J.A., Arthur, J.W., Nordlie, K.J., Hermanutz, R.O., Standen, D.A., Henry, T.P., 1983. Acidification effects on macro invertebrates and fathead minnows (Pimephales promela) in outdoor experimental channels. Water Res. 17, 47-63. 